\title{
Thysanoplusia orichalcea (FABRICIUS, 1775) (Lepidoptera, Noctuidae, Plusiinae) found again in Romania after more than 150 years
}

\author{
Levente SzÉKELY \& Vlad DinCĂ
}

\begin{abstract}
Summary: Thysanoplusia orichalcea (FABRICIUS, 1775) is recorded in the Romanian fauna based on a specimen collected at Enisala Fortress (northern Dobrogea, Tulcea County). This specimen represents the first record in the country in over 150 years. Some aspects regarding the presence of this species in Romania are clarified.
\end{abstract}

Rezumat: Thysanoplusia orichalcea (FABRicius, 1775) este semnalată în fauna României pe baza unui exemplar colectat la Cetatea Enisala (nordul Dobrogei, județul Tulcea). Acesta reprezintă prima semnalare din țară în peste 150 de ani. Sunt clarificate unele aspecte privind prezența acestei specii în România.

Key words: Dobrogea, Romania, Thysanoplusia orichalcea.

\section{Introduction}

Thysanoplusia orichalcea (FABRICIUS, 1775) is a paleotropical species that is usually common in Indochina, India and A frica, but also occurs across vast areas of Pacific Asia and reaches Papua New Guinea, Australia and New Zealand (HILl et al. 1987, GOATER et al. 2003, BehouneK et al. 2010). In Europe, it is a regular migrant in southern (Mediterranean) areas, but a very rare occurrence further north (GOATER et al. 2003, BEHOUNEK et al. 2010). It has occasionally been recorded as far north as southern England, southern Ireland and The Netherlands (KARLSHOLT

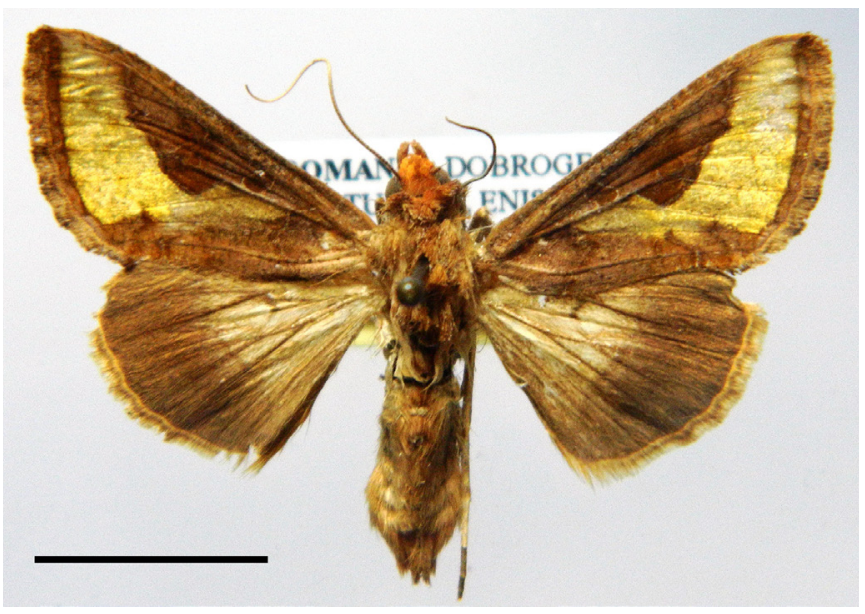

Fig. 1. Thysanoplusia orichalcea, Enisala Fortress, Tulcea county, northern Dobrogea, 24.VII.2020. Scale bar is $10 \mathrm{~mm}$. (Photo: L. Székely) and RAZOWSKi 1997, GOATER et al. 2003).

In certain parts of its range, $T$. orichalcea can become a considerable pest on legumes, in particular soybean (e.g. TAYLOR and KunJeKu 1983, COMMON 1990), but larvae can infest a variety of other crops such as parsley, lucerne, cabbage, carrot etc. (e.g. HILL et al. 1987).

\section{Results}

Material: 19, 24.VII.2020, Romania, Dobrogea, Tulcea county, Enisala Fortress, $88 \mathrm{~m}\left(44.8833^{\circ} \mathrm{N}\right.$, $28.8355^{\circ} \mathrm{E}$ ) (leg. L. Székely and V. Dincă) (Fig. 1).

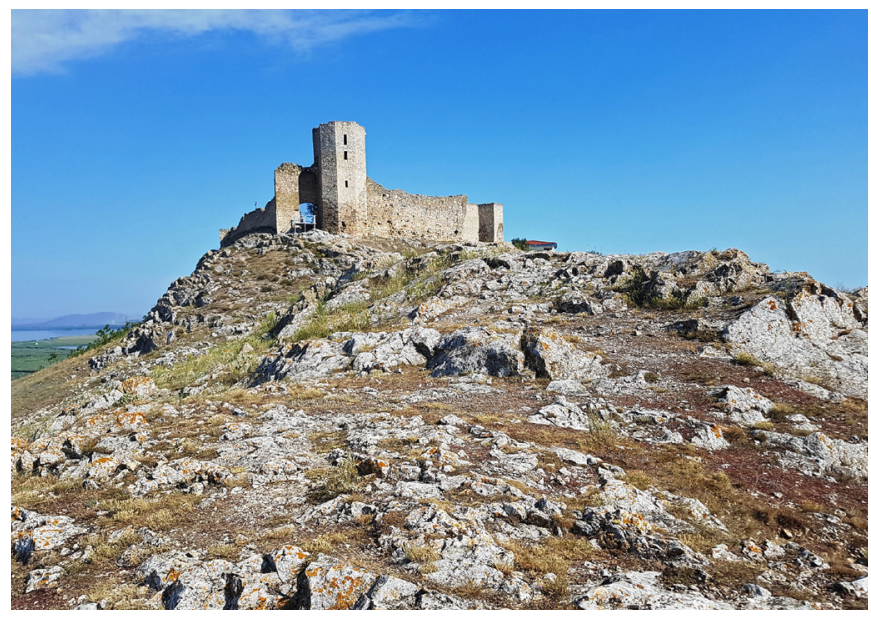

Fig. 2. Enisala Fortress, Tulcea county, northern Dobrogea, 25.VII.2020. (Photo: L. Székely) 


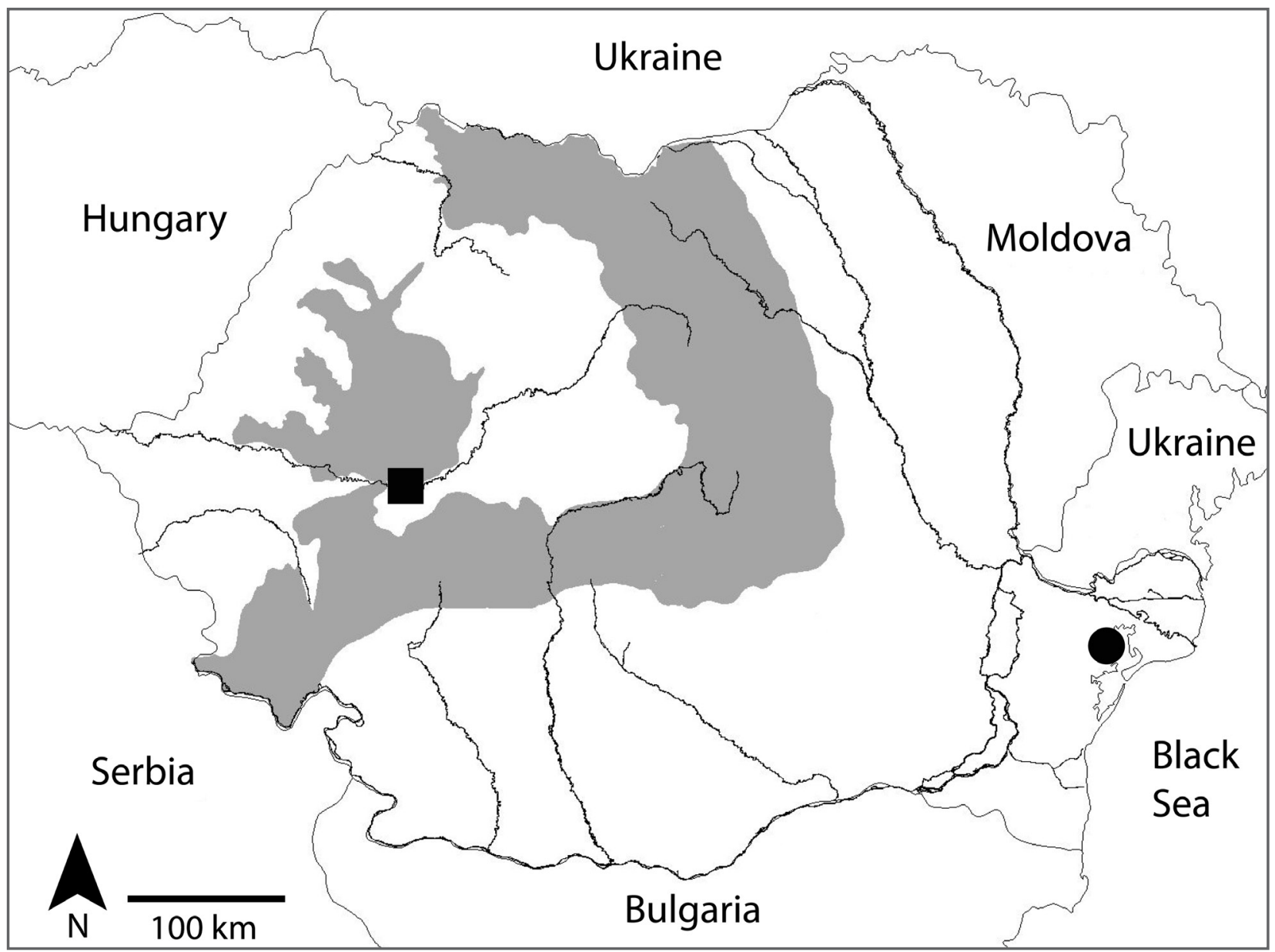

Fig. 3. Records of Thysanoplusia orichalcea in Romania. Black square: nineteenth century record from Săcărâmb, Hunedoara county (Fuss 1850); black dot: current record from Enisala Fortress, Tulcea county.

The material was collected using a light trap with a 16W UV tube, on the limestone slopes surrounding Enisala Fortress (Figs. 2,3). The material captured with the same trap during that night included other species such as Chelis maculosa (Gerning, 1780), Odice suava (HüBNER, 1813), Hecatera cappa (HüBNER, [1809]), Lacanobia blenna (HÜBNER, 1824) etc.

\section{Discussion}

Thysanoplusia orichalcea was reported only twice from Romania: from Săcărâmb / Nagyág (today in Hunedoara county) (Fuss 1850, taken over by various authors such as Czekelius 1897, RÁKosy 1996, RÁKosY et al. 2003); and from Tulcea (northern Dobrogea) (RÁKosY et al. 2003 citing MANN 1866).

To our knowledge, the record from Săcărâmb (Fuss 1850) is not backed by any specimen preserved in museum or private collections.

We do not confirm the record from Tulcea (RÁkosY et al. 2003) since T. orichalcea is not mentioned in the paper by MANN (1866), neither as such, or using its synonyms chrysitina MARTYN, 1897 and aurifera HÜBNER, [1813] (GOATER et al. 2003).

Therefore, the specimen from Enisala Fortress represents the only record documented with a sampled specimen in Romania, and the first record since the mid-nineteenth century (Fig. 3). The limestone steppe (Fig. 2) from Enisala Fortress represents the habitat for several species with very restricted distribution in Romania and/or Europe such as Ocnogyna parasita (HÜBNER 1790), Scopula orientalis (ALPHÉRAKY, 1876), Eublemma porphyrinia (FREYER, 1845), Cucullia santonici (HüBNER, [1813]), Dichagyris melanura (Kollar, 1846), Chersotis laeta macini RÁKosy, StANGelmaier \& Wieser, 1996 etc. (SzÉKely 2016a, 2016b, DinCĂ and SZÉKELY 2018).

In countries neighbouring Romania, T. orichalcea is known as very sporadic from Bulgaria (ABADJIEV and Beshoov 2007) and Serbia (Stojanović and ĆurČIĆ 2011).

It remains to be seen whether the frequency of this species in Romania will increase in the future, or if it will remain an exceptionally rare migrant. Possibly as a result of climate change, during the last two decades, certain other subtropical-tropical species have entered or have apparently become noticeably more common in south-eastern Romania, such as Grammodes bifasciata (Petagna, 1787), Aedia leucomelas (LinnaEus, 1758), Chrysodeixis chalcites (EsPER, 1789), Mythimna unipuncta (HAwOrTH, 1809) etc.

\section{Acknowledgements}

We thank László Rákosy for comments on a previous version of the manuscript. Support for this research was provided by the Academy of Finland to Vlad Dincă (Academy Research Fellow, decision no. 328895). 


\section{References}

Abadjiev S. and Beshkov S. (2007) Prime Butterfly Areas in Bulgaria. Pensoft series faunistica 69. Pensoft Publishers, Sofia, 222 pp.

Behounek G., Ronkay L. and Ronkay G. (2010) Plusiinae II. A Taxonomic Atlas of the Eurasian and North African Noctuoidea. Vol. 4. Heterocera Press, Budapest, 276 pp.

Common I.F.B. (1990) Moths of Australia. Carlton, Melbourne University Press, 535 pp.

Czekelius D. (1897) Kritisches Verzeichnis der Schmetterlinge Siebenbürgens. Verhandlungen und Mitteilungen des Siebenbürgischen Vereins für Naturwissenschaften zu Hermannstadt 47: 1-78.

DINCĂ V. and SzÉKELY L. (2018) First record of Scopula orientalis (Alphéraky, 1876) (Lepidoptera, Geometridae) in Romania, at the northern limit of the Balkans. Nota Lepidopterologica 41(2): 189-197.

Fuss C. (1850) Verzeichnis der bis jetzt in Siebenbürgen aufgefundenen Lepidopteren. Verhandlungen und Mitteilungen des Siebenbürgischen Vereins für Naturwissenschaften zu Hermannstadt 1: 54-64.

Goater B., Ronkay L. and Fibiger M. (2003) Catocalinae \& Plusiinae. Noctuidae Europaeae vol. 10. Sorø, Entomological Press, $452 \mathrm{pp}$.

Hill M.G., Cameron P.J., Dugdale J.S., Allan D.J. and WALKer G.P. (1987) Biology of Thysanoplusia orichalcea (Lepidoptera: Noctuidae) in New Zealand.
New Zealand Entomologist 10: 44-50.

KaRsholt O. and RAzOWSKI J. (1996) The Lepidoptera of Europe - A Distributional Checklist. Apollo Books, Stenstrup, $380 \mathrm{pp}$.

ManN J. (1866) Aufzählung der im Jahre 1865 in der Dobrudscha gesammelten Schmetterlinge. Verhandlungen der Kaiserlich-Königlichen ZoologischBotanischen Gesellschaft in Wien 16: 1-40.

RÁKosy L. (1996) Die Noctuiden Rumäniens. Staphia, Linz, $648 \mathrm{pp}$.

Rákosy L., Goia M. and Kovács Z. (2003) Catalogul LepidopterelorRomâniei/VerzeichnisderSchmetterlinge Rumäniens. Societatea Lepidopterologică Română, $446 \mathrm{pp}$.

Stojanović D.V. and ĆurČIĆ S.B. (2011) The diversity of noctuid moths (Lepidoptera: Noctuidae) in Serbia. Acta Zoologica Bulgarica 63(1): 47-60.

SzÉKELY L. (2016a) Early spring Lepidoptera (Insecta: Lepidoptera) from Dobrogea (South-Eastern Romania). Brukenthal Acta Musei 11(3): 421-432.

SzÉKELY L. (2016b) New and rare macrolepidoptera (Insecta) from Romanian Dobrogea (south-east Romania). Travaux du Muséum National d'Histoire Naturelle «Grigore Antipa» 59(2): 195-230.

TAYlor D.E. and KunJeKu E. (1983) Development of an economic threshold for semi-loopers (Lepidoptera: Noctuidae) in soya-beans in Zimbabwe. Zimbabwe Journal of Agricultural Research 21: 89-100.
Levente SZÉKELY

Bd. George Moroianu 29, Săcele, 505600, Jud. Brașov, Romania

E-mail: levi.szekely@gmail.com

Received: 31.08 .2020

Accepted: 15.09 .2020

Published online: 30.09 .2020

Published: 31.12.2020

Online article number: ER24202004

doi: 10.24193/entomolrom.24.4
Vlad DINCĂ

Ecology and Genetics Research Unit,

University of Oulu, PO Box 3000,

Oulu, 90014, Finland

E-mail:vlad.e.dinca@gmail.com 